\title{
Budidaya Pakan Lebah Trigona sp. dengan Apiculture Agroforestry System di Kelurahan Anjungan Melancar Kabupaten Mempawah
}

\author{
Syarif Muhammad Syaifudin, Sigit Normagiat
}

\author{
Universitas Nahdlatul Ulama Kalimantan Barat \\ E-mail : girasfatihsigit@gmail.com
}

DOI: https://doi.org/10.21107/pangabdhi.v6i1.6932

Naskah diterima 2 Februari 2020, Revisi 30 Maret 2020, Terbit 19 April 2020

\begin{abstract}
Abstrak
Mitra berada di Kabupaten Mempawah yaitu Desa Anjongan Melancar di Kecamatan Anjongan. Salah satu usaha budidaya yang kini mulai diminati oleh masyarakat terutama di Kelurahan Anjungan melancar dan Desa Galang adalah Budidaya madu Kelenceng atau Kelulut (Trigona sp.). Dalam kegiatan Pengabdian kami memberikan dua hal yang menjadi solusi permasalahan mitra di Anjungan Melancar yaitu teknis budidaya pakan lebah kelulut dengan menggunakan Apiculture Agroforestry System dan edukasi perbaikan manajemen pemasaran madu kelulut. dalam hal Pemasaran masyarakat sudah menggunakan media sosial dan sebagai media pemasaran, dan sebagian besar produk madu yang dihasilkan sudah memiliki branding. Sehingga kegiatan edukasi pemasaran difokuskan tentang bagaimana masyarakat dapat mengelola dinamika persaingan antar peternak dan prilaku konsumen madu kelulut. Sedangkan dari aspek budidaya tim memberikan bantuan bibit sebanyak 1200 bibit pohon berbunga dari jenis Kaliandra, tanah mineral Podsolik Merah Kuning (PMK), dan alat-alat pertanian untuk mendukung perawatan tanaman. Tim pelaksana pengabdian mengadakan kegiatan bimbingan teknis tentang bagaimana menanam di lahan gambut untuk jenis pohon dan pola penanaman yang tepat. Hasil pemantauan terhadap hasil yang diperoleh mengindikasikan bahwa masyarakat memahami dan dapat mengaplikasikan Apiculture Agroforestry System. jenis kaliandara ditanam sesuai panduan yang diberikan sehingga dapat tumbuh baik di lahan milik peternak madu kelulut. Diharapkan dalam 2-3 tahun kedepan tanaman kaliandara dapat berbunga dan menjadi pakan yang dapat meningkatkan kulitas madu kelulut yang dikelola oleh kelompok peternak di Anjungan Melancar dan sekitarnya.
\end{abstract}

Kata Kunci : apiculture agroforestry system, kaliandra, kelulut, madu, trigona sp.,

\section{PENDAHULUAN}

Mitra adalah Peternak Kelulut di Kelurahan Anjungan Melancar Kecamatan Anjungan, Kabupaten Mempawah Kalimantan Barat. Sumber pendapatan utama daerah yang menunjang perekonomian Kabupaten Mempawah berasal dari sektor peranian dan perikanan luas lahan pertanian Kabupaten mempawah 84,47 \% diantaranya terdiri dari lahan sawah $14,41 \%$ dan pertanian bukan sawah $72,06 \%$. Ketersediaan lahan budidaya pertanian yang cukup luas memungkinkan masyarakat untuk membuka berbagai macam usaha budidaya sambilan seperti peternakan, perikanan, dan kehutanan (BPS, 2017).

Salah satu usaha budidaya yang kini mulai diminati oleh masyarakat terutama di Kelurahan Anjungan melancar adalah Budidaya madu Kelenceng atau Kelulut (Trigona sp.). Harga jual madu Kelulut yang lebih tinggi dibanding madu lebah hutan (Apis sp) serta perawatannya yang mudah membuat masyarakat tertarik untuk membudidayaannya. Harga terkini madu Kelenceng dijual pada kisaran harga 300 ribu rupiah per kilogramnya di tingkat distributor sedangkan madu lebah biasa berkisar 200 ribu rupiah per kilogramnya (Kamaruddin, 2002).

Kandungan gizi madu Kelulut juga telah diteliti lebih baik dibanding dengan madu lebah biasa. Sebagai contoh propolis yang dihasilkan dari Trigona sp. Memiliki aktivitas antimikroba terhadap bakteri Salmonella (Hasan et.al, 2011). kualitas madu Kelulut juga sama baiknya dengan madu hutan (Apis dorsata) dalam mengendalikan kadar kolesterol darah (Rahma et.al., 2014). Perbandingan karakteristik madu hutan dan Kelulut dapat dilihat pada Tabel 1 berikut : 
Tabel 1. Perbandingan Karakteristik Madu Apis dan Madu Kelulut

\begin{tabular}{|l|l|l|}
\hline Perbandingan & Madu Hutan & \multicolumn{1}{|c|}{$\begin{array}{c}\text { Madu } \\
\text { Kelulut }\end{array}$} \\
\hline Rasa & $\begin{array}{l}\text { Cenderung } \\
\text { manis }\end{array}$ & $\begin{array}{l}\text { Cenderung } \\
\text { asam, kecut, } \\
\text { pahit }\end{array}$ \\
\hline Propolis & $\begin{array}{l}<1 \quad \text { kg per } \\
\text { tahun }\end{array}$ & $\begin{array}{l}8,5 \text { kg per } \\
\text { tahun }\end{array}$ \\
\hline $\begin{array}{l}\text { Kandungan } \\
\text { enzim }\end{array}$ & $\begin{array}{l}\text { Relatif sedikit } \\
\text { jenis }\end{array}$ & $\begin{array}{l}\text { Lebih beragam } \\
\text { jenisnya }\end{array}$ \\
\hline Kelembapan & Sekitar 20\% & Sekitar 30\% \\
\hline
\end{tabular}

Kondisi geografis Kabupaten Mempawah sangat mendukung perkembangbiakan lebah Kelenceng. Lebah ini dapat hidup baik di dekat lahan pertanian, hutan rawa gambut bahkan dapat hidup di hutan mangrove. Lebah ini tergolong memiliki daya adaptasi yang sangat baik sehingga dapat dibudidayakan di dekat pemukiman penduduk. Bentuk dan sarang koloni dari dua spesies lebah Kelulut yang berbeda dapat dilihat pada Gambar 1 berikut :
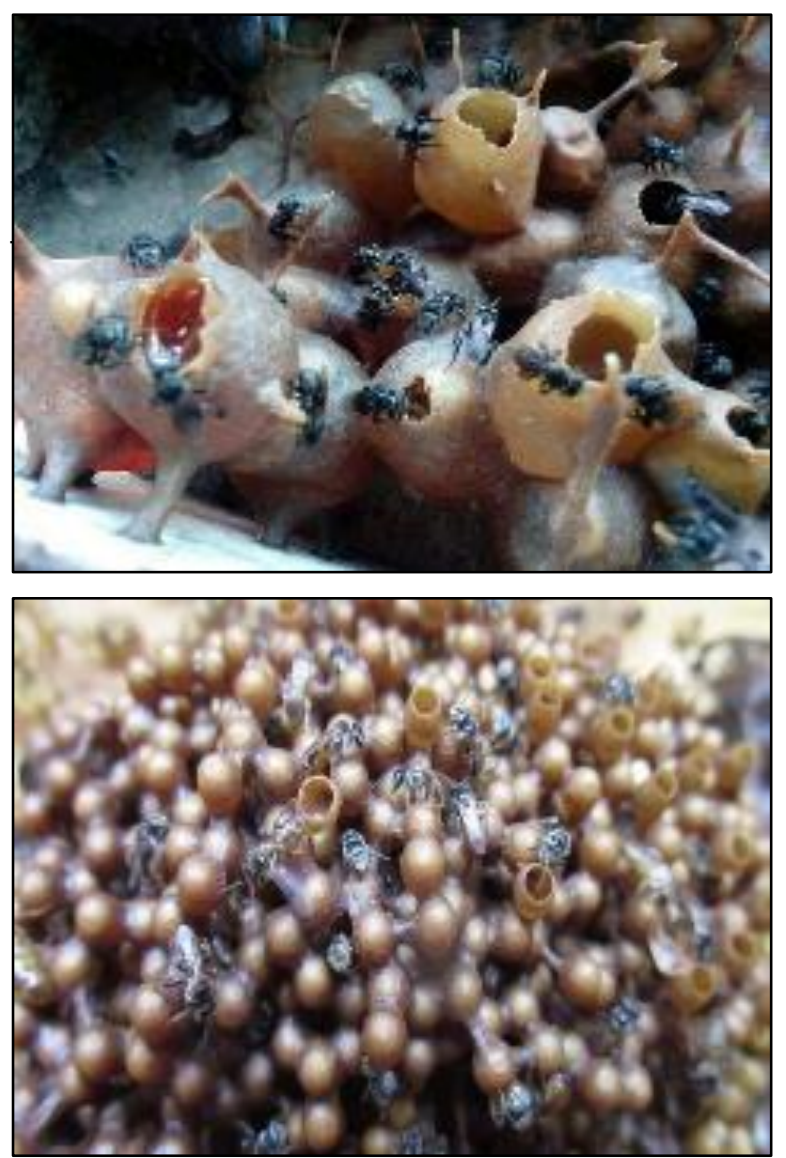

Gambar 1. Dua Spesies Lebah KeKelulut yang Dibudidayakan oleh Warga Desa Anjungan: Trigona itama (atas), Trigona leavieceps (bawah).
Peternak memelihara lebah di dalam kandang yang di dalamnya terdapat kotak atau batang kayu yang menjadi tempat bersarang koloni lebah Kelulut. Disekitar kandang terdapat tanaman maupun tumbuhan liar berbunga yang bisa menjadi sumber nektar yang menjadi diantara penentu kualitas rasa dari madu yang dihasilkan. Gambar 2 merupakan cuplikan kandang dan tanaman yang ditemukan di lokasi pengabdian.
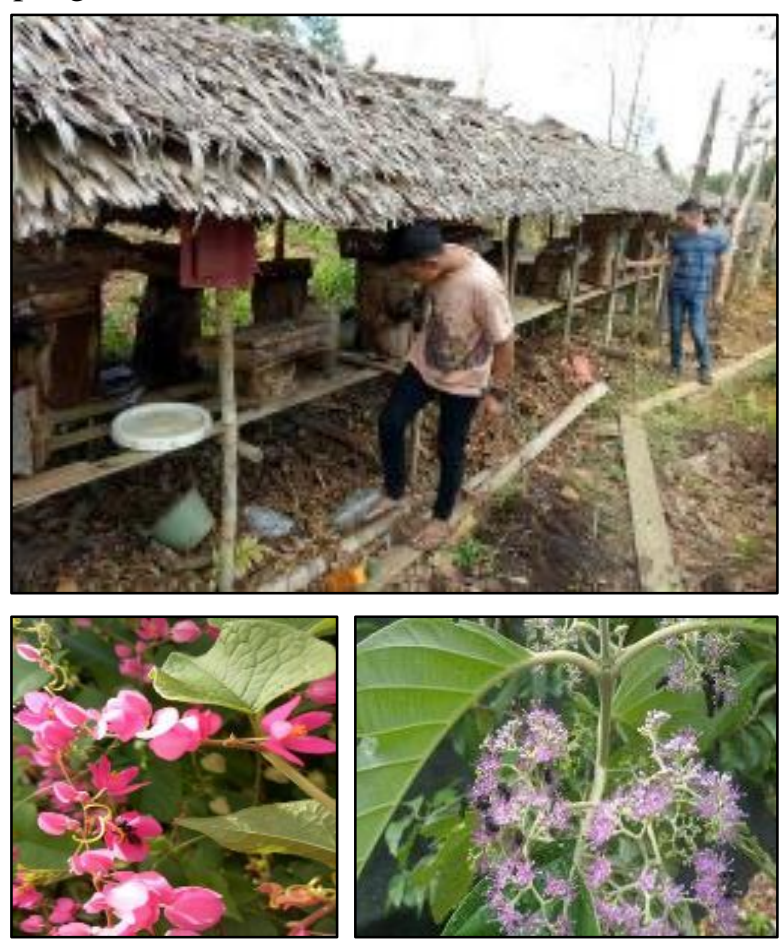

Gambar 2. Model kandang lebah Kelulut yang sering digunakan peternak (atas); jenis bunga yang menjadi pakan kesukaan lebah Kelulut (kanan bawah) adalah bunga air mata pengantin (Antigonon sp.) dan bunga liar yang masih belum diketahui nama binomialnya (kiri bawah).

Saat ini kelompok peternak berhasil menghasilkan hingga $100 \mathrm{~kg}$ madu Kelulut per bulan yang dihasilkan dari kurang lebih 400 koloni. Berdasarkan analisis situasi maka diketahui dua masalah utama yang dihadapai oleh peternak madu Kelulut yaitu terkait pengetahuan teknis tentang budidaya pakan untuk peningkatan produksi madu, masyarakat juga terkendala pada pemasaran dan branding produk. serta persaingan yang kontra-produktif antar peternak madu Kelulut dalam memenuhi kebutuhan pasar.

\section{METODE}

Kegiatan Kemitraan Masyarakat Stimulus dimulai pada bulan Mei 2019 dengan melalui 
tiga tahapan. Pertama, adalah mengidentifikasi permasalahan yang dihadapi peternak baik yang berasal dari kondisi biofisik lahan seperti tipe tanah, jenis vegetasi, dan pengelolaan lahan yang dilakukan maupun dari segi bisnis madu yang dijalankan. Tahap kedua adalah memberikan pelatihan materi yang diberikan terkait konsep bisnis madu dan budidaya pakan lebah Kelulut menggunakan Apiculture Agroforestry System. mengingat lahan yang dijadikan lokasi merupakan lahan yang sudah ditanami, maka model agroforestry yang dipilih adalah penanaman di batas lahan atau disebut trees along borders Tahap ketiga adalah tahap penerapan materi pelatihan dalam hal ini peternak dipandu dan diberikan peralatan pertanian pendukung dalam pelaksanaannya, serta dilakukan kontrol hingga tanaman pakan yang dibudidayakan menunjukkan indikasi pertumbuhan yang baik.

Perlu diperhatikan bahwa pada prinsipnya suhu ideal yang disukai lebah Kelulut berkisar 18 -24 derajat celcius, sehingga untuk areal kandang lebah yang terbuka memerlukan naungan pohon atau ditutup dengan paranet, kelembapan yang diperlukan berkisar $60-70 \%$. Lingkungan sekitar yang disukai adalah lingkungan yang banyak terdapat vegetasi penghasil bunga sebagai sumber makanannya. Lebah Kelulut memakan serbuk sari yang berasal dari tanaman dan tumbuhan liar di sekitar koloninya hingga radius antara 100-500 meter (Manuhuwa et.al., 2011).

\section{HASIL DAN PEMBAHASAN}

Pelaksanaan Program Kemitraan Masyarakat Stimulus (PKMS) dimulai pada bulan awal bulan Mei 2019, dimana Tim mengunjungi Kelurahan Anjungan Melancar dan melakukan orientasi lapangan tentang kondisi sosial masyarakat peternak Kelulut dan kondisi lahan yang akan dijadikan lokasi budidaya Pakan Lebah Kelulut. Dari hasil orientasi tersebut didapati bahwa, kondisi lahan di kelurahan anjungan melancar merupakan lahan peralihan dari tanah organik (gambut) ke tanah mineral (podsolik). Di wilayah yang memiliki tanah organik memiliki resiko yang sangat tinggi terhadap terjadinya kebakaran beberapa lokasi menjadi titik api bahkan hingga kepinggiran jalan raya.

Hal ini tentunya sangat mengganggu pelaksanaan kegiatan, karena denga terjadinya kebakaran suhu di lokasi menjadi meningkat dan berdampak negatif jika dilakukan penanaman bibit yang belum dapat beradaptasi dengan lingkungan tanam yang baru. kondisi lahan di anjungan melancar merupakan lahan peralihan dari tanah organik (gambut) ke tanah mineral (podsolik). Di wilayah ini memiliki resiko yang tinggi terhadap terjadinya kebakaran lokasi titik api bahkan hingga kepinggiran jalan raya. Gambar 3 menunjukkan lahan yang terbakar tersebut.

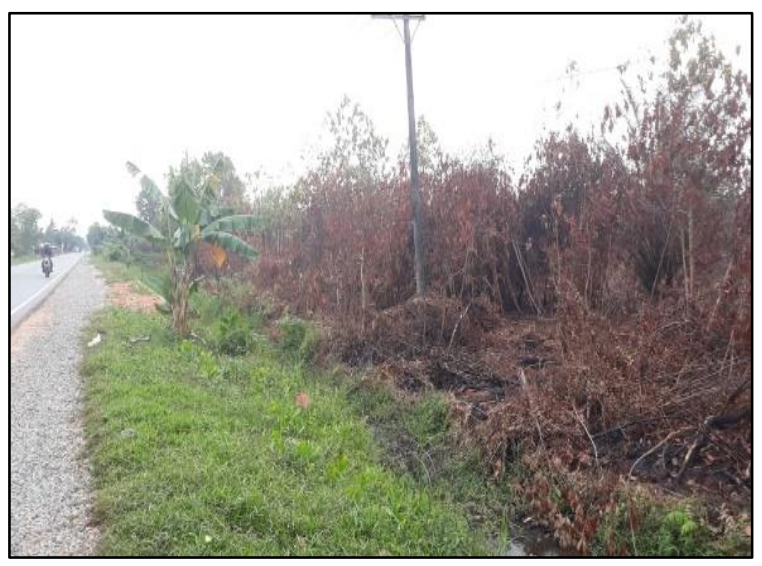

Gambar 3. Sisa Kebakaran Lahan Gambut Di Jalan Menunju Lokasi Kegiatan Pengabdian

Kondisi kebakaran lahan yang terjadi dan musim kemarau menjadi hambatan kami dalam mengadakan kegiatan lebih awal. Karena proses penanaman bibit pakan madu Kelulut mebutuhkan kondisi musim penghujan dalam intensitas sedang. Selain itu kondisi asap yang dihasilkan dari kebakaran hutan membuat sebagian dari kandang lebah milik para peternak ditinggalkankan oleh koloninya. Sebagai solusinya tim melakukan penyesuaian jadwal sampai situasi menjadi lebih kondusif untuk dilaksanakan kegiatan pelatihan maupun penanaman. Sehingga kegiatan ini dimulai kembali di akhir bulan Juli 2019. Sebelum memulai rangkaian kegiatan PKMS kami mendetailkan kembali situasi lahan yang digarap oleh masyarakat, agar desain Apiculture Agroforestry System yang kami buat tidak betentangan atau merusak lahan budidaya yang sudah ditanami dan ditata oleh masyarakat. sebagian besar masyarakat yang bertempat tinggal di lahan gambut mengusahan dengan berkebun nanas.

\section{Kegiatan Pelatihan}

Kegiatan pelatihan dilaksanakan pada tanggal 25 Agustus 2019 mengenai Pemasaran madu dan budidaya pakan lebah madu Kelulut menggunakan Apiculture Agroforestry System. Bertindak sebagai narasumber tentang 
manajemen pemasaran madu adalah saudara Syarif Muhammad Syaifudin, M.M, dari Fakultas Ekonomi Manajemen UNU Kalbar yang juga sebagai praktisi madu di Kalimantan Barat. Sedangkan narasumber tentang budidaya pakan lebah adalah Sigit Normagiat M.Sc dari Fakultas Pertanian UNU Kalbar. Persiapan acara dan asistensi di lapangan dibantu oleh dua orang mahasiwa dari Fakultas Pertanian UNU Kalbar yaitu Silma Setyowati (Agroteknologi, NIM: P0217001) dan Hafizah (Agribisnis, NIM : P0117001). Suasana pelatihan dapat dilihat pada Gambar 4 berikut.
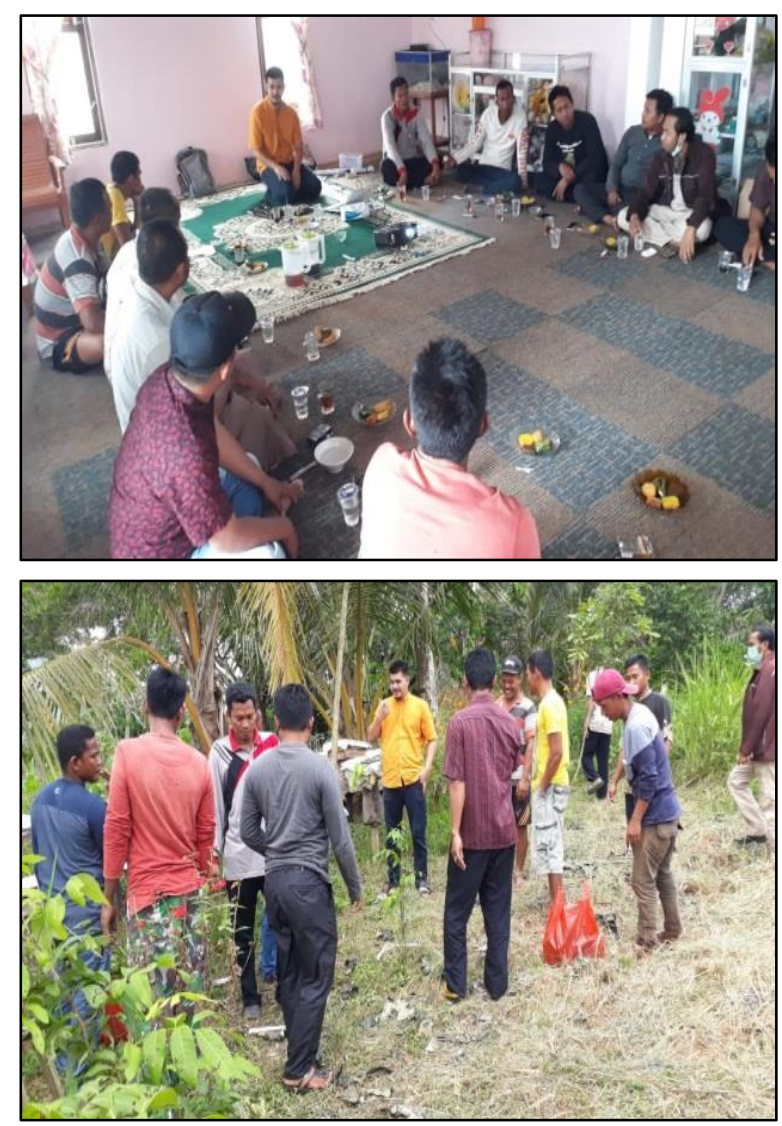

Gambar 4. Suasana Pelatihan dan Praktek

Penanaman Jenis Kaliandra Sebagai Aplikasi Apiculture Agroforestry System dengan

Menggunakan Model Trees Along Borders

Sesi pertama kegiatan pelatihan dijelaskan tentang agroforestri dan berbagai macam aplikasinya. Keunggulan yang diperoleh dari sisi peningkatan produktivitas lahan dan kelestarian lingkungan. Aplikasi Agroforestri di lahan gambut memerlukan perlakuan yang khusus. Lahan gambut memiliki tingkat keasaman yang tinggi sehingga untuk bertanam di lahan ini harus memperhatikan pemilihan jenis tanaman yang cocok dengan karakteristik gambut. Introduksi tanaman membutuhkan proses adaptasi, perlakuan rekayasa tempat tumbuh harus dilakukan sebelumnya. Dalam perencanaan penananaman kami memberikan input tanah mineral pada setiap lubang tanam yang akan ditanami bibit jenis pakan lebah.

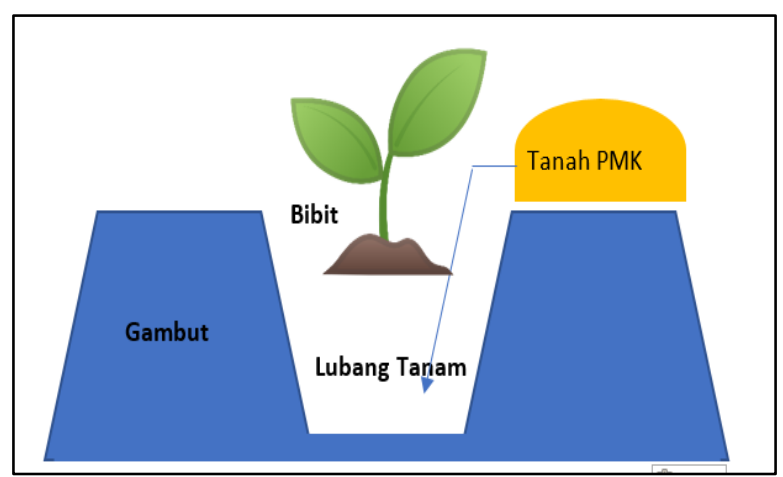

Gambar 4. Lubang Tanam Diisi Tanah Mineral Untuk Proses Adaptasi Bibit Dengan Lahan Gambut

Agroforestri memiliki beberapa aplikasi model tanam diantaranya adalah Alley Cropping, Alternate row, Random mixture, dan trees along borders. Berdasarkan hasil analisis situasi di lapangan maka kami merekomendasikan desain yang tepat untuk penanaman jenis pakan adalah menggunakan trees along borders yaitu model penanaman dimana vegetasi pohon ditanami mengelilingi batas luasan lahan, hal tersebut dilaksanakan dengan pertimbangan bahwa sebelumnya sudah ada tanaman pokok masyarakat yang sudah ditanam di lahan tersebut. Lebih jelasnya dapat dilihat pada Gambar 5 berikut :

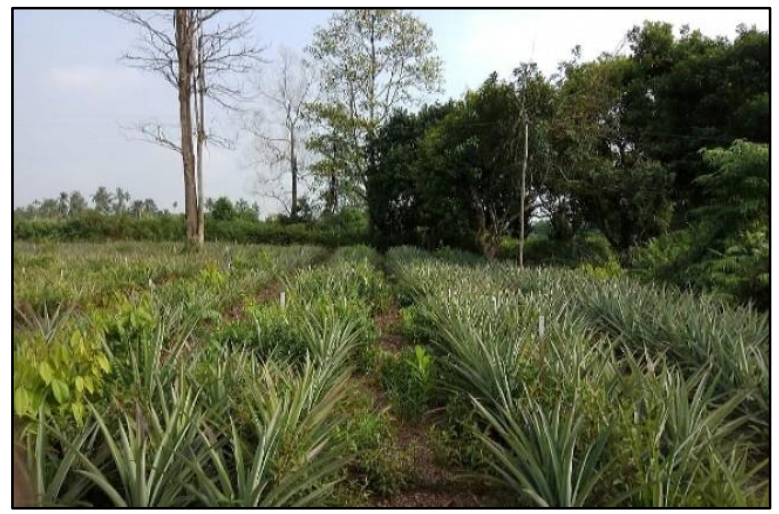

Gambar 5. Ilustrasi Model Tanam

Kondisi vegetasi berbunga pada lokasi di Anjungan sudah cukup banyak, yang menjadi unggulan adalah bunga air mata pengantin yang dibudidayakan di sekitar pekarangan rumah warga. Tumbuhan tersebut dapat berbunga sepanjang tahun, dan terdapat beberapa vegetasi yang menyediakan bunga namun secara musiman seperti pohon jambu air dan rambutan. 
Penanaman jenis vegetasi berkayu pada areal gambut memiliki kendala yaitu dalam hal konsistensi tanah untuk tegak tumbuhnya tanaman, serta adaptasi sepesies pohon terhadap tingkat keasaman tanah. Hal tersebut menyebabkan jenis pohon yang dapat ditanam menjadi terbatas. Padahal keberadaan pohon penghasil buah mempunyai pertan penting sebagai sumber pakan lebah Kelulut, buahnya untuk memenuhi konsumsi masyarakat, dan juga menjadi pohon tersebut dapat menjadi pelindung terhadap kerusakan lahan.

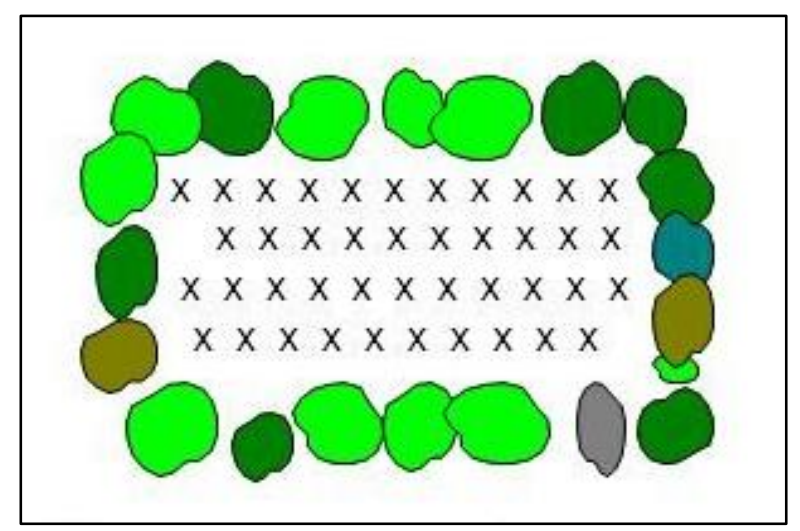

Gambar 6. Lahan Budidaya dengan Tanaman Pokoknya Nanas Sketsa Trees Along Border

Kondisi vegetasi berbunga pada lokasi di Anjungan sudah cukup banyak, yang menjadi unggulan adalah bunga air mata pengantin yang dibudidayakan di sekitar pekarangan rumah warga. Tumbuhan tersebut dapat berbunga sepanjang tahun, dan terdapat beberapa vegetasi yang menyediakan bunga namun secara musiman seperti pohon jambu air dan rambutan.

Penanaman jenis vegetasi berkayu pada areal gambut memiliki kendala yaitu dalam hal konsistensi tanah untuk tegak tumbuhnya tanaman, serta adaptasi spesies pohon terhadap tingkat keasaman tanah. Hal tersebut menyebabkan jenis pohon yang dapat ditanam menjadi terbatas. Padahal keberadaan pohon penghasil buah mempunyai pertan penting sebagai sumber pakan lebah Kelulut, buahnya untuk memenuhi konsumsi masyarakat, dan juga menjadi pohon tersebut dapat menjadi pelindung terhadap kerusakan lahan.

Hasil diskusi dengan masyarakat, selama ini produsen madu mengeluh banyak konsumen yang komplain tentang rasa dari madu Kelulut yang cenderung asam. dan menyangka produk mereka palsu. Sedangkan jika dibandingkan antara madu Kelulut (Trigona sp.) dan madu hutan (Apis sp.) memiliki perbedaan dalam karakteristik dalam hal rasa dan konsistensi bentuk. Madu hutan cenderung lebih kental dan manis dibandingkan dengan madu Kelulut yang lebih encer dan asam.

Pemilihan jenis Kaliandra (Caliandra sp) sebagai sumber pakan lebah Kelulut merupakan hal yang tepat. karena berdasarkan pengalaman uji coba peternak Kelulut bahwa nektar dari bunga jenis kaliandra dapat membuat citarasa madu Kelulut menjadi lebih manis. sayangnya ketersediaan jenis pohon ini masih sangat sedikit di kelurahan anjungan. Berikut pada Gambar 7 adalah bibit kaliandra dan karakateristik bunganya.
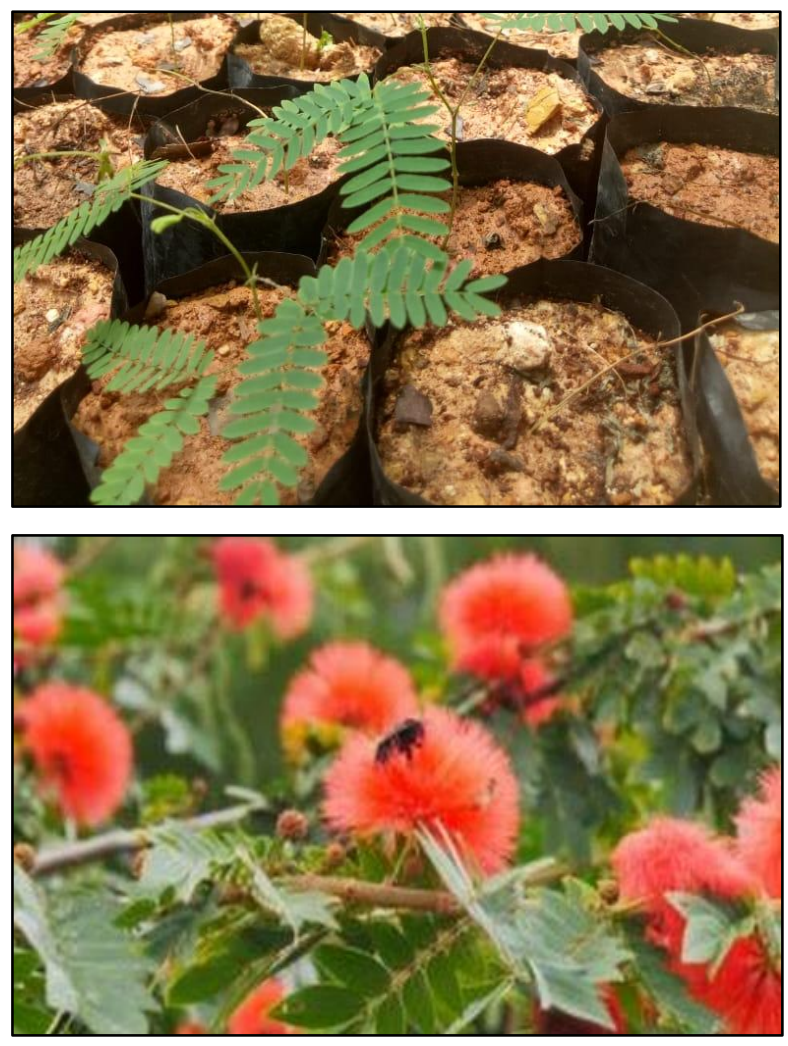

Gambar 7. Karakteristik Bibit Kaliandra dan

Bunga yang Menjadi Sumber Pakan Lebah Kelulut

Penyediaan pakan dari jenis vegetasi yang membuat citarasa manis pada madu merupaka usaha peternak untuk menyesuikan madu yang diprouksi terhadap selera konsumen. Padahal, pembudidaya madu juga perlu memiliki kemampuan pemasaran dalam mengedukasi konsumennya khususnya konsumen baru yang mencoba madu Kelulut. Bahwa madu yang encer dan cenderung masam merupakan karakteristik alami dari madu jenis madu Kelulut. Kedua hal inilah yang selama ini menjadi kendala dalam pengembangan usaha madu bagi masyarakat anjungan dan sekitarnya. 


\section{Penanaman Bibit}

Penyediaan bibit untuk keperluan penanaman jenis yang bisa dimanfaatkan sebagai sumber pakan, diperoleh melaui kerjasama dengan Balai Pengelolaan Daerah Aliran Sungai dan Hutan Lindung (BPDASHL) Kalimantan Barat. Adapun jenis yang disediakan terutama adalah jenis Kaliandra, disamping itu terdapat jenis lainnya berupa bibit durian, bibit rambutan, dan bibit tanaman unggulan lokal untuk pengayaan keanegaraman jenis pakan di areal peternakan Kelulut. Pada pelaksanaan penanaman bibit dilakukan secara bertahap karena stock bibit yang tersedia di pembibitan BPDASHL di Pontianak masih sangat muda, sebagai solusinya kami medatangkan stock bibit siap tanam dari persemaian yang ada di Kabupaten Melawi sekitar $300 \mathrm{~km}$ dari Pontianak untuk terlaksananya kegiatan penaman

Masyarakat diberikan arahan untuk persiapan lahan pertanaman. Bibit merupakan tanaman muda yang rentan terhadap stres lingkungan terutama kondisi keasaman lahan gambut. Mengatasi permasalahan tersebut dalam program ini kami juga memberikan tanah mineral subur sebagai untuk digunakan sebagai media penanaman bibit sebanyak 15 dump truck yang dibagikan kepada peternak yang kondisi lahannya bergambut, selain hal tersebut tim PKMS juga menghibahkan alat-alat pertanian dan pupuk untuk perawatan selama masa pertumbuhan tanaman sumber pakan lebah madu Kelulut. Peralatan-peralatan yang diterima oleh peternak Kelulut dan proses penyiapan lahan dapat dilihat pada Gambar 8 berikut :
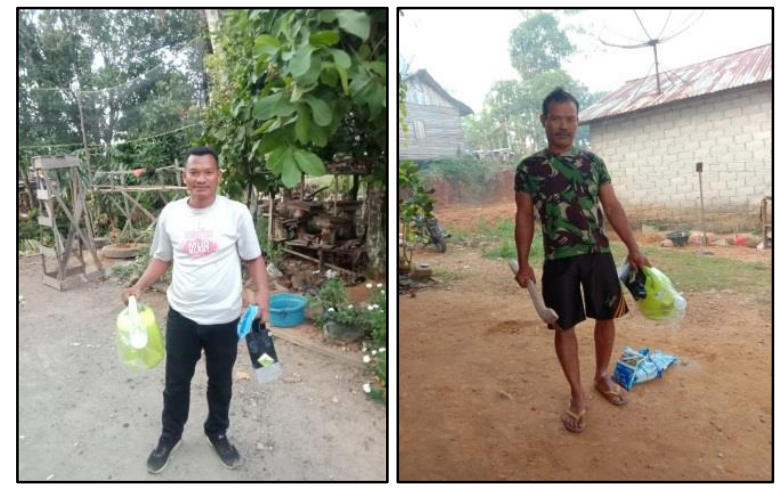

Gambar 8. Alat yang Diterima oleh Peternak untuk Digunakan dalam Persiapan Lahan,

Penanaman dan Perawatan Tanaman Kaliandra

Bibit Kaliandra yang ditanam di lahan yang relatif terbuka membutuhkan paranet sebagai naungan buatan agar tidak mengalami stress akibat sinar matahari berlebih. Penanaman secara agroforestri di buat sedemikian rupa agar tanaman tertata, meminimalisir persaingan yang terjadi antar tanaman pokok yang telah ada dengan tanaman yang baru ditanam.
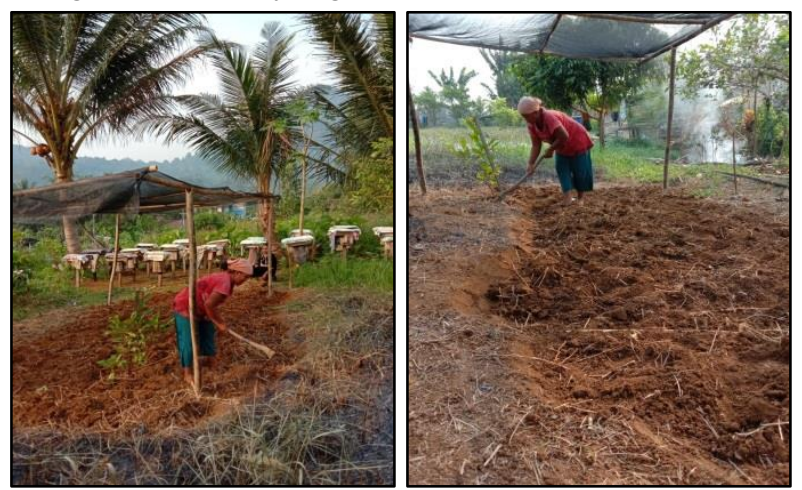

Gambar 9. Proses Penyiapan Lahan untuk Menanam Bibit Kaliandra

Sebagai rangkaian kegiatan kami memantau pertumbuhan tanaman Kaliandra yang telah ditanam oleh masyarakat peternak Kelulut. Dari hasil inspeksi yang kami lakukan bahwa kaliandra dapat tumbuh baik. Dikarenakan tanaman ini membutuhkan waktu beberapa tahun untuk berbunga maka kami belum dapat mencatat kontribusi adanya kaliandra terhadap kenaikan produksi madu Kelulut yang didapat oleh para peternak. Selama pertumbuhan tanaman Kaliandra, para peternak melakukan panen raya pada akhir bulan Oktober 2019. Pada saat panen raya hasil yang diperoleh para petani lebih banyak dari panen pada bulan-bulan lainnya. Diharapkan dengan adanya pengayaan pakan Kelulut dari jenis kaliandra 2 -3 tahun kedepan hasil panen di bulan-bulan di luar panen raya juga akan mengalami peningkatan, juga kualitas rasa madu Kelulut semakin diminiati oleh konsumen dengan cita rasa yang lebih manis yang diperoleh dari nektar bunga kaliandra
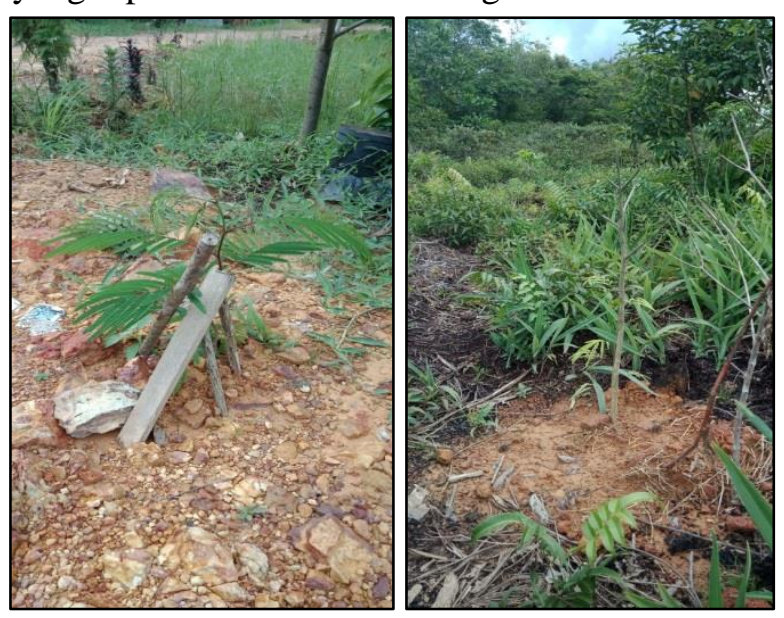

Gambar 10. Pertumbuhan Kaliandra di Lahan Milik Peternak Kelulut 
Hasil evaluasi yang kami dapatkan bahwa di tanah bergambut dengan kedalaman hingga $>1$ $\mathrm{m}$ memerlukan volume tanah PMK yang lebih banyak. Hal tersebut dapat dibandingkan hasil pertumbuhan dari kiri ke kanan tanah yang diberikan volumenya semakin sedikit menghasilkan pertumbuhan bibit tanaman menjadi lebih lambat. Kedepanya dengan ketersedian dan variasi sumber pakan yang cukup peternak dapat melakukan perbanyakan sarang koloni yang baru. Pembuatam sarang dapat dimodifikasi dari kotak kayu kering, tempurung kelapa, atau bambu. Bagian terpenting adalah membuatkan tutup yang diberi lubang kecil (diameter $1 \mathrm{~cm}$ ) agar sarang tersebut terhidar dari panas atau hujan yang berlebihan (5). Sarang yang baru yang telah siap digunakan ditempelkan dengan sarang lama. Sarang Kelulut biasanya berbentuk pipa meamanjang seperti belalai, akan lebih lebih baik lagi jika bagian ini yang dipotong dan dijadikan jembatan penghubung antara sarang yang lama dengan sarang barunya (6). Cara lain adalah dengan mencari dan memindahkan ratu lebah Kelulut pada sarang yang baru.

\section{Rencana Tahap Berikutnya}

Kegiatan yang telah dilaksanakan yang meliputi Pelatihan dan Penanaman Vegetasi Pakan Lebah madu Kelulut telah selesai dilaksanakan. Rencana berikutnya dapat berupa kegiatan perawatan lanjutan terhadap vegetasi meliputi pemupukan pemangkasan (prunning) agar dihasilkan pertumbuhan bunga yang maksimal nantinya, melakukan kontrol terhadap kemungkinan terjadinya stress biotik meliputi serangan hama penyakit dan gulma.

Tim pelaksana pengabdian juga telah membuat Whatsapp Group (WAG) yang dapat dilihat pada Gambar 11. Fungsi WAG tersebut adalah untuk memberikan bantuan kosultasi terkait budidaya dan dinamika pemasaran madu Kelulut yang dihadapi oleh peternak. Atas dasar masukan yang kami terima dari masyarakat agar melanjutkan program kegiatan pengabdian yang telah dilakukan, maka di tahap berikutnya kami akan mengupayakan membuat pengajuan anggaran baru untuk mengadakan pelatihan kelembagaan dan penerapan teknologi tepat guna dalam mendukung produksi dan pemasaran madu Kelulut yang dihasilkan oleh masyarakat.

Potensi sumberdaya lainnya yang ada di wilayah anjungan adalah berupa pertanian padi sawah, sumber air mineral untuk dijadikan air kemasan maupun depot air isi ulang. Kondisi air yang baik juga mendorong masyarakat di lokasi kegiatan sukses dalam perikanan air tawar dari jenis ikan nila. Potensi-potensi ini juga perlu mendapat perhatian dalam program pengabdian kedepannya.

Selesainya Kegiatan Pengabdian Masyarakat Stimulus dalam ruang lingkup melatih masyarakat untuk mempraktekan kegiatan budidaya agroforestri dan dasar manajeman pemasaran telah memberikan bekal pemahaman dan kemampuan dalam mengembangan budidaya madu Kelulut bersama tanaman lainnya secara Apiculture Agroforestry System serta mendorong sinergi antar anggota peternak maupun antar kelompok peternak untuk melahirkan inovasi baru dalam memenuhi atau menciptakan pasar baru produk madu Kelulut.

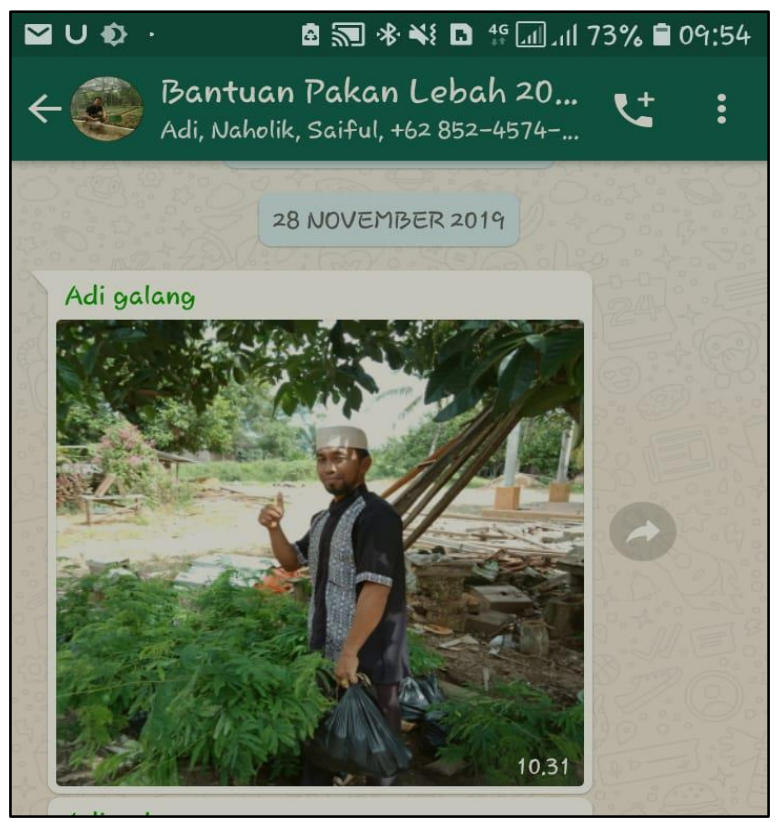

Gambar 11. Screen Shot WA Group Pembudidaya Lebah Madu Kelulut

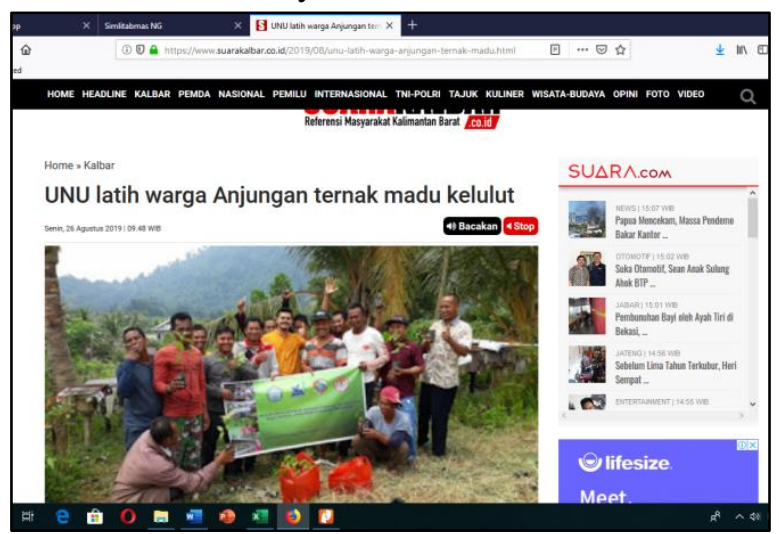

Gambar 12. Pemberitaan Pada Media Online Lokal tentang Kegiatan Pengabdian Masyarakat

Kegiatan Pengabdian Masyarakat Stimulus dalam ruang lingkup melatih masyarakat untuk 
mempraktekan materi yang diberikan telah selesai dilakukan. Untuk selanjutnya masayarakat sudah memiliki bekal pemahaman dan kemampuan dalam mengembangan budidaya madu Kelulut bersama tanaman lainnya secara Apiculture Agroforestry System. Kegiatan pengadian ini diberitakan dalam media lokal suarakalbar.co.id pada bulan Agustus 2019 (Gambar 12).

\section{KESIMPULAN}

Program Kemitraan Masyarakat stimulus yang dilaksanakan telah menjawab kebutuhan para peternak madu di Kelurahan anjungan dan sekitarnya. Kegiatan yang dilakukan berupa Pelatihan, penanaman dan pemberian bantuan alat-alat pertanian mendapatkan respon yang positif dari masyarakat. Setelah dilakukan pendampingan hingga akhir pelaksanaan pengabdian, saat ini masayarakat telah memiliki pemahaman dan kemampuan dalam menerapkan budidaya pakan menggunakan apiculture agroforestry sytem pada lahan disekitar peternakan madu mereka. masyarakat dapat mengembangkan lebih lanjut sistem ini dengan menambah variasi tanaman pakan dari jenis-jenis lainnya.

Pelaksanaan program pengabdian memerlukan koordinasi yang matang baik antara tim pelaksana maupun dengan masyarakat target, supaya kegiatan dapat terlaksana tepat waktu dan efisiesien. Tim pengabdian harus tetap fokus tehadap ruang lingkup kegiatan, hal-hal lain terkait permintaan masyarakat diluar lingkup tersebut dapat ditampung sebagai rencana pada tahap selanjutnya.

\section{UCAPAN TERIMA KASIH}

Tim pengabdian kepada masyarakat mengucapkan terima kasih kepada pihak yang berkontribusi dalam pengabdian ini yaitu: Direktorat Riset dan Pengabdian kepada Masyarakat, Direktorat Jendral Penguatan Riset dan Pengembangan, Kementerian Riset, Teknologi, dan Pendidikan Tinggi.

\section{DAFTAR PUSTAKA}

BPS. 2017. Mempawah Dalam Angka. https://pontianakkab.bps.go.id/publikasi.html

Hasan A. E. Z, Artika I. M., Fatoni A., Kuswandi, Haryanto B. 2011. Antibacterial Activity of Propolis Trigona Spp. from Bukittinggi West Sumatera Against Salmonella Sp.Chem. Prog. Vol. 4, No.2

Kamaruddin. 2002. Khasiat Madu. Departement of Biochemistry, Faculty of Medicine, Universitas of Malaya,Kuala Lumpur

Manuhuwa, E., Loiwatu, M., Lamberkabel, J. S., \& Rumaf, I. 2011. Produksi Madu, Propolis dan Roti Lebah Tanpa Sengat (Trigona spp) Dalam Sarang Bambu. Prosiding Seminar Nasional Masyarakat Peneliti Kayu Indonesia (MAPEKI) XVI, (pp. 251-259). Yogyakarta.

Rahma S, Natsir R, Kabo P. 2014. Pengaruh Antioksidan Madu Dorsata dan Madu Trigona Terhadap Penghambatan Oksidasi LDL pada Mencit Hiperkolesterolemia. JST Kesehatan. Vol 4. No 4. 377 - 384 pp.

Riendriasari, S. D. 2013. Budidaya Lebah Madu Trigona sp Mudah dan Murah. Makalah Altek BPTHHBK.1-5 